\title{
Intravesical Migration and Calcification of Intrauterin Device: A Case Report and Review of the Literature
}

\section{Rahim İci Aracın Mesaneye Migrasyonu ve Taşlaşması: Olgu Sunumu ve Literatür Taraması}

\author{
Levent Verim1, Alpaslan Akbaș2, Mehmet Remzi Erdem1 \\ 1 Haydarpaşa Numune Training and Research Hospital, Clinic of Urology, İstanbul, Turkey \\ 2Onsekiz Mart University Faculty of Medicine, Department of Urology, Çanakkale, Turkey
}

\begin{abstract}
Intrauterine device (IUD) is widely used for the long duration of protection, cost-effectiveness and for being a reversible contraceptive method as well as having low complication rates. Despite low complication rates, various IUD-related complications, such as spontaneous aborts, bleeding, infection, and uterine perforation may occur. Although perforation of the uterus by an IUD is not uncommon, bladder perforation is a rare complication. A regular follow-up of patients with IUDs for the complications and training of clinicians for insertion and removal are mandatory to provide better and safe family planning services. Here, we report a case of a patient with uterine perforation with a calcified IUD migration into the the bladder.
\end{abstract}

\section{Keywords}

Intrauterine device, pregnancy, migration, intravesical calculus

\section{ÖZ}

Rahim içi araçlar (RiA) uzun süreli etkinliği, ucuz olması ve kolaylıkla çıkartılabilirliğiyle kontrasepsiyonda yaygın kullanım alanı bulmuştur. RiA'nın kullanımında düşük komplikasyon oranlarına rağmen spontan abortus, kanama, enfeksiyon ve uterus perforasyonu gibi komplikasyonlar ile karşılaşılmaktadır. Uterus perforasyonu çok seyrek olmamakla birlikte RiA'nın mesane perforasyonu çok seyrek karşılaşılan bir komplikasyondur. RiA uygulanmış olguların komplikasyon gelişme riski açısından düzenli takibi ve RíA uygulayacak sağlık personelinin eğitimi aile planlamasının güvenilirliği için gereklidir. Bu yazıda mesaneye migrate olmuş ve taşlaşmış bir olgu ve ilgili literatür bilgileri sunulmuştur.

\section{Anahtar Kelimeler}

Rahim içi araç, gebelik, migrasyon, mesane taşı

\section{Introduction}

Contraception has become a worldwide concern during the past five decades due to the rapid increase in human population. Approximately half of the pregnancies are unintended. The contraceptive options to reduce the risk of unintended pregnancy include sterilization, intrauterine device (IUD), hormonal contraception and barrier. IUD is the most popular reversible and cost-effective contraceptive method (1). The invention of the copper 'T' shaped IUD in the 1960s brought the high efficacy for fertility regulation. The hormonal IUD was also invented in the 1960s and 1970s. Various complications, such as unplanned pregnancy, spontaneous abortion, bleeding, dysmenorrhea, infection, uterine perforation were observed in the advancing years with the usage of IUD. Uterine perforation may occur during device insertion. Second hypothesis is that perforation may occur by migration of the IUD through uterine wall, through gradual pressure. Perforation may be facilitated by uterine contractions. IUD migration into adjacent organs can lead to appendicitis, bowel penetration, fistula formation, intraperitoneal adhesions leading to infertility, vesical penetration with stone formation, and obstructive nephropathy. Removal of dislocated IUD must be performed in symptomatic patients due to potential complications (2).

\section{Case Presentation}

We report a 27-year-old multipara without previous caesarean delivery in whom an IUD eroded from the uterus a few years after placement. The device remained asymptomatic in the pelvis for an additional 4 years before the patient presented with urinary symptoms. She had become pregnant and had urinary symptoms during last two years. Six years elapsed between intrauterine insertion of the device

\section{Correspondence}

Levent Verim MD, Haydarpaşa Numune Training and Research Hospital, Clinic of Urology, İstanbul, Turkey

Phone: +90 21654232 32/16 39 E-mail: leventverim@yahoo.com Received: 12.11.2015 Accepted: 16.11.2015 
and its retrieval with the calculus from the bladder. The patient had experienced suprapubic and lower abdominal pain, urinary urgency, dysuria, and intermittent hematuria. Suprapubic tenderness was found on physical examination. Urinalysis showed 20-25 leukocytes and 25-30 blood cells per high-power field. But the urine culture showed no growth of microorganism. A plain abdominal x-ray revealed a T-shaped radio opaque shadow in the pelvis. Ultrasonography of the bladder demonstrated vesical calculus measuring $5 \mathrm{~cm}$ in length and $3.3 \mathrm{~cm}$ in width and the diagnosis was confirmed by cystoscopy. While performing cystolithotripsy, pneumatic lithotripter failed and the stone was retrieved intact with a suprapubic transvesical miniincision. There was no visible defect or fistulae in the bladder wall. The rough and calcified T-shaped mass was containing a T-shaped copper IUD (Figure 1). The patient was discharged on the postoperative day 3 without any complication.

\section{Discussion}

IUD is the most popular and widespread used method of birth control among fecund young women in Turkey. In the screening of medical

\section{Table 1. Distrubition of intravesical dislocated intrauterine}

device issues and intrauterine device use rates

\begin{tabular}{|c|c|c|c|c|}
\hline Country & Years & $\begin{array}{l}\text { Total } \\
\text { intravesical } \\
\text { IUD issues } \\
\text { (total 155)* }\end{array}$ & $\begin{array}{l}\text { Population } \\
\text { (X106) }\end{array}$ & $\begin{array}{l}\text { IUD use } \\
(\%)^{* *}\end{array}$ \\
\hline Turkey & 1998-2015 & 34 & 77 & 16.9 \\
\hline Tunusia & $2001-2011$ & 19 & 11 & None \\
\hline India & 1974-2014 & 15 & 1.195 & 1.8 \\
\hline USA & 1978-2014 & 10 & 320 & 5.2 \\
\hline Nigeria & $2003-2013$ & 9 & 170 & 0.7 \\
\hline Iran & $2007-2007$ & 8 & 78 & 7.6 \\
\hline Pakistan & $2002-2011$ & 8 & 173 & 2.3 \\
\hline Taiwan & 1999-2011 & 6 & 23 & None \\
\hline U. K. & $1985-2010$ & 5 & 51 & 10 \\
\hline Spain & $1977-2005$ & 4 & 46 & 6.4 \\
\hline Mexico & $1995-2005$ & 3 & 118 & 11.6 \\
\hline Egypt & 1993-2013 & 3 & 87 & 36.1 \\
\hline China & 2015-2015 & 3 & 1.350 & 40.6 \\
\hline France & 1999-2013 & 3 & 66 & 18.9 \\
\hline Cuba & 1997-2008 & 3 & 11 & 24.9 \\
\hline Italy & 2011-2015 & 2 & 61 & 5.8 \\
\hline Japan & 2011-2013 & 2 & 126 & 0.9 \\
\hline Chile & 1993-2011 & 2 & 17 & 18.9 \\
\hline Morocco & $1999-2004$ & 2 & 33 & 4.2 \\
\hline Russia & 1997-2006 & 2 & 144 & 20.4 \\
\hline Tahiland & 1999-2001 & 2 & 67 & 0.9 \\
\hline Others & $1988-2011$ & 10 & None & None \\
\hline \multicolumn{5}{|c|}{$\begin{array}{l}\text { IUD: Intrauterine device, } \\
\text { *NCBI databases and PubMed Related Articles; IUD migration and bladder; Backfiles } \\
\text { to } 1974 \text {, } \\
\text { **UN world Contraceptive Patterns Wall Chart } 2013 \text {. }\end{array}$} \\
\hline
\end{tabular}

literature, we found 155 case reports of IUD migration into the bladder with or without calcification included in PubMed and 34 of 155 cases were documented from Turkey. Interestingly, Turkish publications related to IUD complications were more in number than those from other countries (Table 1).

Uterine perforation is the most common serious complication of this contraception method and can be asymptomatic for a long time after IUD insertion. The rate of uterine perforation is estimated 1 per 1000 applications (3). A rare complication of IUD is its migration into the structures close to the uterus or into the peritoneal cavity although IUD has a low rate of complication. Bladder perforation by an IUD has seldom been diagnosed because of its rarity. Fragility of the uterine wall due to pregnancy, recent birth or abortion is the causes of migration of IUD into the bladder. These migrations may be overlooked assuming that the device had fallen out $(4,5)$.

Migration of an IUD into the bladder is a less frequent occurrence than the existence of other foreign bodies in the bladder for reasons such as iatrogenic causes (IUD inserted by mistake transurethral with thindiameter applier, broken resectoscope loop, nonabsorbable suture etc.) or migration of materials used for masturbation into the bladder. Foreign bodies in the bladder lumen may lead to stone development. Intravesical migration of an IUD also causes calcium precipitation on the metal parts of the device, which is followed by calculus formation in a short period of time. Then, persistent and recurrent cystitis, which usually respond temporarily to antibiotic and antispasmodic therapy, occurs. Attacks of cystitis starting shortly after insertion of an IUD should arouse suspicion of a bladder perforation and unanticipated pregnancy should heighten suspicion (6). There is one case report of bladder squamous cell carcinoma associated with chronic irritation due to a migrated IUD (7).

The other locations of IUD migration described in the literature are small bowel mesentery, rectosigmoid lumen, appendix vermiformis, anterior and posterior cul-de-sac, space of Retzius, ovarium, etc. $(8,9)$.

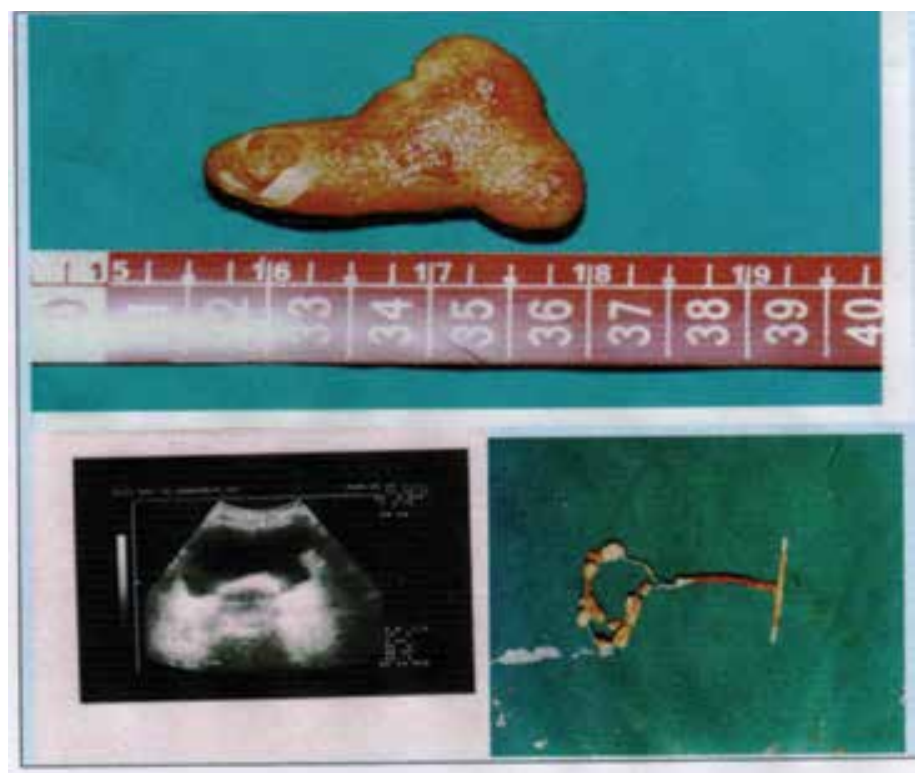

Figure 1. T-Shaped stone (top), a high-echoic mass in the bladder ultrasound (bottom left) and cooper-T intrauterine device (bottom right) 
The IUD stone in the bladder has objective evidence of microscopic pyuria and hematuria, as well as a positive urine culture. Preliminary investigation is preferable beginning with plain abdominal x-ray in anteroposterior and lateral positions. Ultrasonography will probably prove the location of IUD but it can be difficult to recognize the partial migration of IUD near the anterior wall of the bladder (10). Cystoscopy is valuable in the diagnosis of foreign body in the bladder and also searching the cause of recurrent urinary infection. Cystoscopy can also help in planning the optimal approach for removing the IUD calculus. Endoscopic retrieval of the fragmented stone and extraction of the remnant of copper-T IUD with cystoscopy using flexible stent grasping forceps should be preferred as a minimally invasive procedure, but huge stones may be removed by open surgery (11).

In conclusion, a regular follow-up of IUDs for the complications would help in earlier detection of migrated IUDs. Proper training of clinicians is mandatory to provide better and safe family planning services. A simple plain abdominal x-ray and, if needed, diagnostic cystoscopy are very important in patients refractory to urinary infection treatment and in young fecund women with unexplained chronic urinary symptoms. Urologists and gynecologists have to be careful while investigating a missing IUD with the presence of pregnancy and/or persistent urinary infection.

\section{Authorship Contributions}

Concept: Levent Verim, Design: Levent Verim, Data Collection or Processing: Alpaslan Akbaş, Analysis or Interpretation: Alpaslan Akbaş, Remzi Erdem, Literature Research: Remzi Erdem, Writing: Levent Verim, Peer-review: Internal peer-reviewed, Conflict of Interest: No conflict of interest was declared by the authors, Financial Disclosure: The authors declared that this study has received no financial support.

\section{References}

1. United Nations, Population Division, Department Of Economic And Social affair, World Contraceptive Use 2013, Consult www.unpopulation. org, New York (http://www.un.org/en/development/desa/population/ publications/pdf/family/worldContraceptivePatternsWallChart2013.pdf).

2. Markovitch 0 , Klein $Z$, Gidoni $Y$, Holzinger $M$, Beyth $Y$. Extrauterine mislocated IUD: is surgical removal mandatory? Contraception 2002;66:105-108.

3. vanGrootheest $K$, Sachs $B$, Harrison-Woolrych $M$, Caduff-Janosa $P$, van Puijenbroek E. Uterine perforation with the levonorgestrelreleasing intrauterine device: analysis of reports from four national pharmacovigilance centres. Drug Saf 2011;34:83-88.

4. Istanbulluoglu MO, Ozcimen EE, Ozturk B, Uckuyu A, Cicek T, Gonen M. Bladder perforation related to intrauterine device. Chin Med Assoc 2008;71:207-209.

5. Tosun $M$, Celik $H_{1}$ Yavuz $E_{1}$ Cetinkaya MB. Intravesical migration of an intrauterine device detected in a pregnant woman. Can Urol Assoc J 2010;4:141-143.

6. Dede FS, Dilbaz B, Sahin D, Dilbaz S. Vesical calculus formation around a migrated copper-T 380-A. Eur J Contracept Reprod Health Car 2006;11:50-52.

7. Gökce MI, Süer $E$, Tangal $S$, Bedük $Y$. Squamous cell carcinoma of the bladder associated with chronic irritation related to a migrated intrauterine device. Scand J Urol Nephrol 2010;44:183-185.

8. Verma U, Verma N. Ovarian embedding of a transmigrated intrauterine device: a case report and literature review. Arch Gynecol Obstet 2009;280:275-278.

9. Kassab B, Audra P. The migrating intrauterine device. Case report and review of the literature. Contracept Fertil Sex 1999;27:696-700.

10. Mahmutyazicioğlu K, Ozdemir H, Ozkan P. Migration of an intrauterine contraceptive device to the urinary bladder: sonographic findings. J Clin Ultrasound 2002;30:496-498.

11. El-Hefnawy AS, El-Nahas AR, Osman Y, Bazeed MA. Urinary complications of migrated intrauterine contraceptive device. Int Urogynecol J Pelvic Floor Dysfunct 2008;19:241-245. 